\title{
Cell Death and Anti-DNA Antibodies
}

Yasuhiko Hirabayashi

Additional information is available at the end of the chapter

http://dx.doi.org/10.5772/48343

\section{Introduction}

Autoantibodies are characteristic features of autoimmune diseases (Table 1). In organ or tissue-specific autoimmune diseases, autoantibodies against cell-surface molecules are usually observed. These antibodies (Abs) stimulate or damage the target cells and cause organ- or tissue-specific diseases. In systemic autoimmune diseases, in addition to anti-cellsurface molecule Abs, Abs against intracellular molecules are frequently observed although B cell tolerance to intracellular molecules is strictly enforced in normal subjects. Some indicate high disease specificity with a high incidence rate. Therefore, such Abs may be closely associated with development of the disease as well as with disease activity. However, it is not known how or why Abs against intracellular molecules are generated.

\section{Role of cell death in the generation of anti-intracellular molecule antibodies}

Cell death, including apoptosis and necrosis, represents a possible source of exposure of intracellular molecules outside the cell. For example, low - intermediate doses $\left(<35 \mathrm{~mJ} / \mathrm{cm}^{2}\right)$ of ultraviolet $\mathrm{B}$ (UVB) induce apoptosis of keratinocytes, resulting in translocation of native DNA, $\mathrm{Ku}$, and $\mathrm{Sm}$ to the cytoplasmic membrane, while a high dose $\left(80 \mathrm{~mJ} / \mathrm{cm}^{2}\right)$ of UVB induces necrosis, resulting in discharge of all of the cell compartments [1]. Intracellular molecules are exposed on the surface blebs of apoptotic cells (apoptotic blebs) [2]. Apoptotic blebs contain fragmented endoplasmic reticulum (ER), ribosomes, ribonucleoprotein, nucleosomal DNA, Ro, La, small nuclear ribonucleoproteins, etc. Autoantigens receive various epigenetic modifications (acetylation, methylation, phosphorylation, dephosphorylation, ADP-ribosylation, ubiquitination, oxidation, transglutamination, citrullination, SUMOylation, etc) during apoptotic cell death [3]. In the case of cytotoxic granule-mediated cell death, granzymes plays an important role in cleavage of autoantigens [4]. These epigenetic modifications may alter preexisting epitopes, expose cryptic epitopes, 


\begin{tabular}{|c|c|c|}
\hline Anti- & Target molecule & Disease \\
\hline \multicolumn{3}{|c|}{$\begin{array}{l}\text { 1. Organ or tissue-specific autoimmune diseases } \\
\text { a. Anti-cell-surface molecules }\end{array}$} \\
\hline \begin{tabular}{|l|} 
TSH receptor* \\
\end{tabular} & TSH receptor & Graves' disease \\
\hline NMDA & N-methyl-D-aspartate receptor & Encephalitis \\
\hline GAD & glutamic acid decarboxylase & Diabetes mellitus type I \\
\hline Ach $^{*}$ & Acetylcholine & Myasthenia gravis \\
\hline myelin associated protein & myelin & Multiple sclerosis \\
\hline ganglioside & ganglioside & Neuropathy \\
\hline
\end{tabular}

\section{b. Anti-intracellular molecules}

\begin{tabular}{|l|l|l|}
\hline mitochondria & mitochondria & PBC \\
\hline thyroid microsomal & thyroid microsomal & Hashimoto's thyroiditis \\
\hline thyroid peroxidase & thyroid peroxidase & Hashimoto's thyroiditis \\
\hline thyroglobulin & thyroglobulin & Hashimoto's thyroiditis \\
\hline
\end{tabular}

2. Systemic autoimmune diseases

a. Anti-cell-surface molecules

\begin{tabular}{|c|c|c|}
\hline PDGF receptor & PDGF receptor & Systemic sclerosis \\
\hline phospholipid* & phospholipid & APS \\
\hline \multicolumn{3}{|c|}{ b. Anti-intracellular molecules } \\
\hline \begin{tabular}{|l|} 
dsDNA $^{*}$ \\
\end{tabular} & dsDNA & SLE \\
\hline Sm & Smith & SLE \\
\hline SS-B & $\mathrm{La} / \mathrm{SS}-\mathrm{B}$ & Sjögren's syndrome \\
\hline centromere & centromere & Systemic sclerosis \\
\hline topoisomerase-I & topoisomerase-I & Systemic sclerosis \\
\hline Jo-1 & histidyl-tRNA synthetase & $\mathrm{DM}$ \\
\hline PR3-ANCA* & proteinase 3 & WG \\
\hline MPO-ANCA* & myeloperoxidase & MPA, AGA \\
\hline
\end{tabular}

TSH: thyroid stimulating hormone; PBC: Primary biliary cirrhosis; PDGF: Platelet-derived growth factor; APS: Antiphospholipid syndrome; dsDNA: double-stranded DNA; SLE: systemic lupus erythematosus; DM: dermatomyositis; WG: Wegener's granulomatosis; MPA: microscopic polyarteritis; AGA: allergic granulomatous angiitis (Churg-Strauss syndrome).

*: The titer of the $\mathrm{Ab}$ is correlated with the disease activity in a proportion of patients.

Table 1. Examples of autoantibodies.

or form novel epitopes, and may contribute to bypassing tolerance to autoantigens [5]. Normally, apoptotic cells are quickly eliminated by professional phagocytes. Delay of apoptotic cell clearance not only increases the time of exposure of intracellular molecules to the immune system but also changes the degree of modification of these molecules, which alters their antigenicity. When clearance fails, apoptotic cells enter the stage of secondary necrosis. The ability to cause inflammation depends on the stage of cell death [6]. Damageassociated molecular patterns (DAMPs), such as HMGB1, SAP130, etc., are released from late apoptotic/necrotic cells into the extracellular space [7-9]. DAMPs activate Toll-like receptors and act as intrinsic adjuvants, resulting in inflammation and initiation of the host immune system. Thus, delay of apoptotic cell clearance increases the risk of an autoimmune response. 


\section{Abnormalities related to apoptosis in SLE}

There are many lupus autoantibodies that bind to autoantigens of apoptotic cells [10]. In SLE, defective clearance of apoptotic cells has been reported. As a result, high levels of circulating early apoptotic cells are found in SLE [11]. T-lymphocytes [12], macrophages/monocytes [13,14], neutrophils [15], and endothelial cells [16] are included among the increased numbers of apoptotic cells. Monocytes and granulocytes, which take up autoantibody remnants of secondary necrotic cell complex, secrete inflammatory cytokines in SLE [17]. These phenomena threaten self-tolerance and are likely involved in the production of lupus autoantibodies [18,19]. The reason for defective apoptotic cell clearance in SLE has yet to be elucidated. It has been suggested that the efficacy of clearance is affected by the cell death trigger, but there have been no reports related to SLE from this viewpoint [20]. Anti-class A scavenger receptor autoantibodies from patients with SLE impair the clearance of apoptotic debris by macrophages [21]. However, the mechanism of autoantibody production is not yet known.

In SLE, the response to early apoptotic cells is also abnormal. Under normal conditions, macrophages secrete antiinflammatory cytokines (IL-10, TGF- $\beta$, PGE2, etc.) to send "tolerate me" signals after ingestion of apoptotic cells [22]. Monocytes from healthy controls showed prominent TGF- $\beta$ secretion and minimal TNF- $\alpha$ production, but monocytes from SLE patients show prominent TNF- $\alpha$ production and diminished TGF- $\beta$ secretion [23]. The authors speculated that this abnormal response may be an intrinsic property of lupus monocytes.

Recent studies have highlighted the role of neutrophils in the pathogenesis and manifestations of SLE [24]. NETosis is a process characterized by the formation of neutrophil extracellular traps (NETs) [25]. NETs become not only a source of intracellular molecules but also immunogens for lupus autoantibodies [26]. Low-density granulocytes (LDGs), an abnormal subset of neutrophils, were identified among the PBMCs derived from patients with SLE [27]. LDGs secrete type I interferons (INFs), have endothelial cytotoxicity, and have higher capacity to form NETs [28]. Degradation of NETs is impaired in patients with SLE [29]. NETs activate complement and deposited C1q inhibits NET degradation [30]. These phenomena increase NETs and may contribute to the production of autoantibodies, including anti-DNA Abs.

It has recently been demonstrated that the source of intracellular molecules is microparticles (MPs), which are small membrane-bound vesicles [31]. MPs, which emerge from the cell membrane during cell activation and apoptosis, contain a variety of cellular components, including nucleic acids [32]. MPs become antigenic targets of anti-DNA Abs, form huge immune complexes in the plasma of patients with SLE, and induce complement activation [33,34].

\section{Anti-dsDNA Abs}

\subsection{Brief historical aspects of anti-dsDNA Abs}

SLE is characterized by the production of a variety of autoantibodies. Especially, antidsDNA Abs are the most characteristic of SLE and contribute to the pathogenesis of lupus 
nephritis. In general, anti-dsDNA Abs are specific for SLE and the anti-dsDNA Abs titer is closely correlated to the activity of lupus nephritis [35]. A proportion of anti-dsDNA Abs are directly involved in immune complex-mediated glomerulonephritis [36]. Thus, the trigger of anti-DNA response may be closely related to the pathogenesis of SLE. However, mammalian native dsDNA is not immunogenic, suggesting that DNA itself does not act as a triggering or driving antigen [37]. The origin of anti-DNA Abs is a long-standing enigma.

Anti-dsDNA responses can be evoked by dsDNA with the aid of a carrier, such as the 27amino acid nucleic acid-binding Fus1 peptide [38], polyoma BK virus large T Ag [39], or DNaseI-dsDNA complex [40] which have been shown to induce production of anti-dsDNA Abs in mice, suggesting a possible role of excess amounts of DNA - protein complex in disruption of tolerance to DNA. Nucleosomes have been suggested as possible Ags responsible for triggering of anti-dsDNA Abs [41,42]. Crude nucleosomes or crude histones [41] have been shown to induce production of anti-dsDNA Abs in mice. Mononucleosomereactive Th clones augment the production of IgG autoantibodies to dsDNA, histones, and histone-DNA complex. However, immunization of $\mathrm{SNF}_{1}$ mice with pure mononucleosomes did not elicit production of IgG anti-dsDNA Abs [43]. HMGB1nucleosome complexes derived from apoptotic cells, but not HMGB1-free nucleosomes, elicited IgG anti-dsDNA Abs in BALB/c mice although their titer was not high, suggesting that adjuvants such as HMGB1 are necessary to break tolerance to dsDNA in nonautoimmune mice [44].

Another possible mechanism is molecular mimicry. Some mouse or human monoclonal anti-DNA Abs have been shown to cross-react with non-nucleic acid self-Ags, such as extracellular matrix protein HP8 [45], heterogeneous nuclear ribonucleoprotein A2 [46], NR2 glutamate receptor [47], $\alpha$-actinin [48,49], ribosomal protein S1 [50], and phospholipids, including cardiolipin [51]. However, it is not yet known whether these molecules can elicit anti-DNA responses.

The peptide, DWEYSVWLSN, is recognized by the R4A mouse monoclonal anti-dsDNA Ab [52]. Immunization with this peptide elicited anti-dsDNA Ab production and caused deposition of IgG in glomeruli in normal mice [53]. These observations indicate that a nonnucleic acid Ag can elicit production of anti-DNA Abs and cause renal disorder in normal animals. However, no proteins containing this peptide sequence have been reported to date.

It should be noted that immunization with recombinant EBNA-1 protein elicited antiEBNA-1 Abs that cross-react with dsDNA, suggesting molecular mimicry between the viral antigen and dsDNA [54]. However, nephritogenicity of the anti-EBNA-1/dsDNA Abs has not been reported.

\subsection{Cross-reactive antigen of the $\mathrm{O}-81$ human nephritogenic anti-DNA mAb}

We prepared human monoclonal anti-DNA Ab, O-81, which binds strongly to singlestranded DNA (ssDNA) and moderately to dsDNA, and demonstrated that the O-81 idiotype (Id) is distributed among IgG anti-DNA Abs of circulating immune complexes as 
well as lupus glomerular deposits [55-58]. The intravenous infusion of IgG isotype antiDNA Abs expressing O-81 Id also caused glomerular IgG deposition in SCID mice [59]. The $\mathrm{VH}$ region of $\mathrm{O}-81 \mathrm{Ab}$ contains many somatic mutations [60]. Similarly, the $\mathrm{VH}$ regions of O-81 Id-positive B cells in patients with SLE were shown to already contain somatic mutations [61]. These observations prompted us to explore the triggering Ags for human nephritogenic anti-DNA Abs using the O-81 Ab.

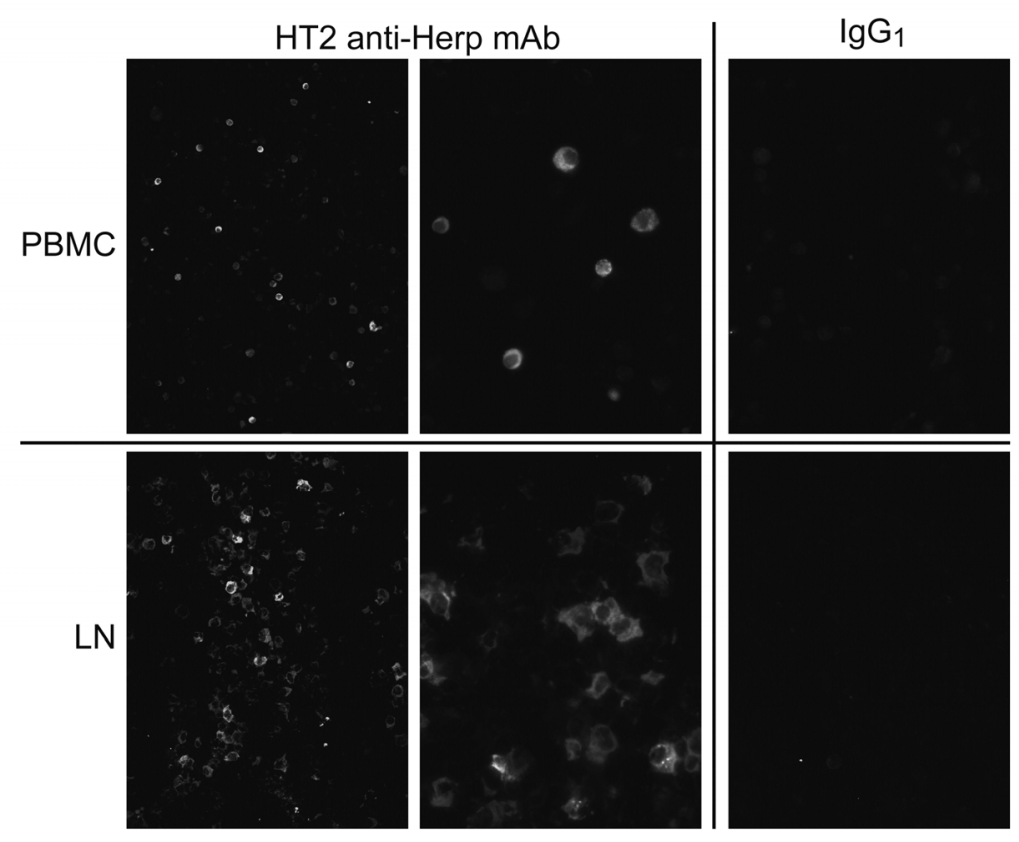

Figure 1. The expression of Herp in peripheral blood mononuclear cells (PBMCs) or the cells in a cervical lymph node (LN) from a patient who developed SLE and had yet to receive treatment.

[Methods] The cells were fixed in 50\% acetone $/ 50 \%$ methanol for $20 \mathrm{~min}$ at $-20^{\circ} \mathrm{C}$ and blocked with $5 \%$ normal goat serum and $3 \%$ BSA in PBS overnight at $4{ }^{\circ} \mathrm{C}$. The cells were then incubated with HT2 mouse monoclonal IgG 1 anti-Herp Ab or mouse IgG1 as an isotype control for $1 \mathrm{~h}$ at room temperature followed by incubation with FITC-conjugated goat $\left.\mathrm{F}(\mathrm{ab})^{\prime}\right) 2$ anti-mouse IgG $\mathrm{Ab}$ (KPL, Gaithersburg, MD) for $1 \mathrm{~h}$ at room temperature [63].

We found that the O-81 Ab specifically cross-reacts with human homocysteine-induced endoplasmic reticulum protein (Herp) [62]. Anti-dsDNA Abs purified from the sera of SLE patients bound to Herp, and anti-Herp Abs purified from the sera of SLE bound to dsDNA [62]. The production of Herp is induced by endoplasmic reticulum (ER) stress. The PBLs from subjects in active SLE, especially at the time of onset or flare-up of the disease, tended to show Herp expression [62]. The expression of Herp was also observed in the lymph node of an untreated patient with active SLE, indicating that Herp can be exposed to the immune system in lymph nodes where Ag recognition occurs (Figure 1). 
Excessive ER stress is known to induce apoptosis [64,65]. Herp can be exposed on apoptotic blebs of ER stress-induced apoptotic cells [62]. Many apoptotic cells expressing Herp were observed in the peripheral blood mononuclear cells (PBMCs) of patients with active SLE, but not normal control subjects [62]. This observation is compatible with those reported previously [11]. These results suggest that Abs against Herp on ER stress-induced apoptotic cells may become anti-Herp/dsDNA cross-reactive Abs, i.e., initial anti-dsDNA Abs.

\subsection{Antigenicity of Herp for anti-dsDNA Ab production in mice}

Immunization of normal BALB/c mice with Herp elicited anti-dsDNA Abs and caused glomerular IgG deposition [62]. However, urinary protein level did not increase and overt nephritis did not develop. The pathological changes in the kidneys in Herp-immunized $\mathrm{BALB} / \mathrm{c}$ mice went no further than silent lupus nephritis.

Nucleosomes, which are major autoantigens in SLE, are exposed at the apoptotic cell surface [66,67]. Anti-nucleosome Abs are present in SLE at a rate of more than $50 \%$ and they have been linked to lupus nephritis [68]. Nucleosomes and histones are present in glomerular deposits [69]. Nucleosomes bind to glomerular endothelial cells and serve as targets for antinucleosome Abs [70]. Therefore, a portion of anti-nucleosome Abs may be involved in lupus nephritis [71]. However, even oligonucleosomes are much less effective than Herp in inducing anti-nucleosome Abs as well as anti-dsDNA Abs [62]. Therefore, to reproduce overt lupus nephritis, BALB/c mice were immunized with Herp followed by immunization with oligonucleosomes. In this procedure, both anti-dsDNA Ab and anti-nucleosome Abproducing clones induced by Herp may be able to recognize oligonucleosomes easily. The production of anti-dsDNA Abs and glomerular IgG deposition were observed in all mice. In addition, overt nephritis with significant proteinuria occurred in one mouse (Figure 2). Although further investigations are in progress to define the mechanisms, it was speculated that (i) the Herp-induced anti-dsDNA Abs efficiently bound to nucleosomes and formed pathogenic immune complexes, and (ii) affinity maturation and epitope spreading of Herpinduced anti-dsDNA Abs occurred by nucleosomes.
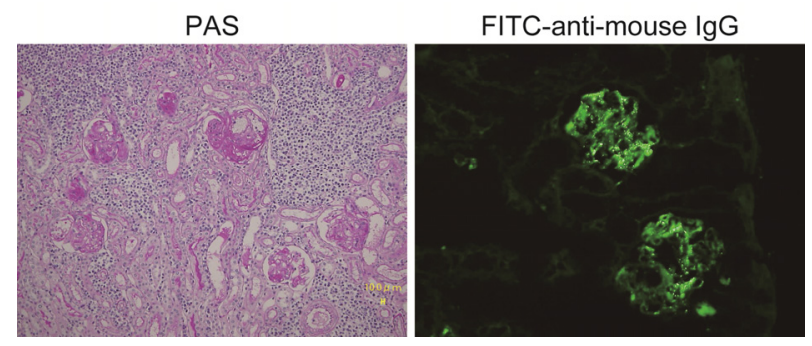

Figure 2. Overt nephritis in a BALB/c mouse immunized with Herp followed by immunization with oligonucleosomes. Left: Periodic acid Schiff (PAS) staining. Right: Immunofluorescence staining with fluorescein isothiocyanate (FITC)-conjugated anti-mouse IgG Ab. 
[Methods] Five 6-week-old female BALB/c mice were immunized intraperitoneally with 100 $\mu \mathrm{g}$ of Herp on days 0 and 10 and $50 \mu \mathrm{g}$ of Herp on day 20, followed by immunization with $10 \mu \mathrm{g}$ of oligonucleosomes on days 30, 40, and 50. Preparation of Herp and oligonucleosomes was described previously [62]. Fresh-frozen tissue sections $4 \mu \mathrm{m}$ thick were fixed in $100 \%$ acetone for $10 \mathrm{~min}$ at $4^{\circ} \mathrm{C}$ and blocked with $5 \%$ normal goat serum and $3 \%$ BSA in PBS overnight at $4^{\circ} \mathrm{C}$. Sections were stained with FITC-conjugated goat $\mathrm{F}\left(\mathrm{ab}^{\prime}\right)_{2}$ anti-mouse IgG $\mathrm{Ab}(\mathrm{KPL})$ for $1 \mathrm{~h}$ at room temperature.

\subsection{Antigenicity of Herp for anti-dsDNA Ab production in humans}

To examine whether Herp can be an antigen for anti-dsDNA Ab production in humans, ELISPOT was performed using PBMCs (representative cases are shown in Figure 3). The number of spots increased when the PBMCs were incubated with Herp, but not with dsDNA, in 4 of 6 untreated active SLE patients (Figure 3A); in 2 of these 4 positive cases, a few spots were observed even in wells without stimulation (Figure 3B). The remaining two cases showed no spots (Figure 3C). On the other hand, no spots were detected in the PBMCs from nine treated active SLE patients, eight inactive SLE patients, and five normal control subjects (data not shown). These results suggest that Herp can stimulate anti-dsDNA antibody-producing clones but this stimulation is cancelled by immunosuppressive therapy.

[Methods] Approximately $1 \times 10^{6}$ PBMCs in $20 \%$ fetal calf serum (FCS)-supplemented RPMI 1640 (20\% FCS-RPMI 1640) were cultured for 5 days with or without $2 \mu \mathrm{g} / \mathrm{mL}$ Herp, or 10 $\mu \mathrm{g} / \mathrm{mL}$ dsDNA. For preparation of dsDNA, calf thymus DNA (Invitrogen, Carlsbad, CA) was pretreated with S1 nuclease (Takara Bio, Otsu, Japan) to remove single-stranded DNA (ssDNA) according to the manufacturer's instructions. Multiscreen 96-well filtration plates (Millipore, Billerica, MA) were coated with $10 \mathrm{mg} / \mathrm{mL}$ protamine overnight at $4^{\circ} \mathrm{C}$, and washed with PBS followed by coating with $10 \mu \mathrm{g} / \mathrm{mL}$ dsDNA in PBS for $2 \mathrm{~h}$ at room temperature. Following blocking with 20\% FCS-RPMI 1640, the cultured PBMCs in $20 \%$ FCS-RPMI were plated at $1 \times 10^{5}$ cells/well and cultured for $24 \mathrm{~h}$. After washing the cells with PBS, goat alkaline phosphatase-conjugated anti-human IgG antibodies (diluted 1:10000; Sigma-Aldrich, St. Louis, MO) were added and the wells were incubated for $1 \mathrm{~h}$ at room temperature. Following a further wash, the spots were visualized using NBT-5-bromo-4chloro-3-indolyl phosphate substrate (Sigma-Aldrich).

\section{Anti-single-stranded DNA (ssDNA) Abs}

The mechanism involved in the production of anti-ssDNA Abs has yet to be elucidated. As ssDNA can have multiple conformational epitopes and all Abs that bind to ssDNA are called anti-ssDNA Abs, these Abs are highly heterogeneous and display low disease specificity. However, the susceptibility of lupus-inducing drugs to anti-ssDNA Ab production is very high. In such cases, there may be a unique mechanism of anti-ssDNA Ab production, as the chemical structures and pharmacological actions of lupus-inducing drugs are known to be highly diverse [72,73]. As higher risk drugs include procainamide and hydralazine, which inhibit DNA methylation, hypomethylation may be one of the causes of anti-ssDNA Ab production, but its precise mechanism remains unknown [74-76]. 
A

case M.S. B

B case S.S.
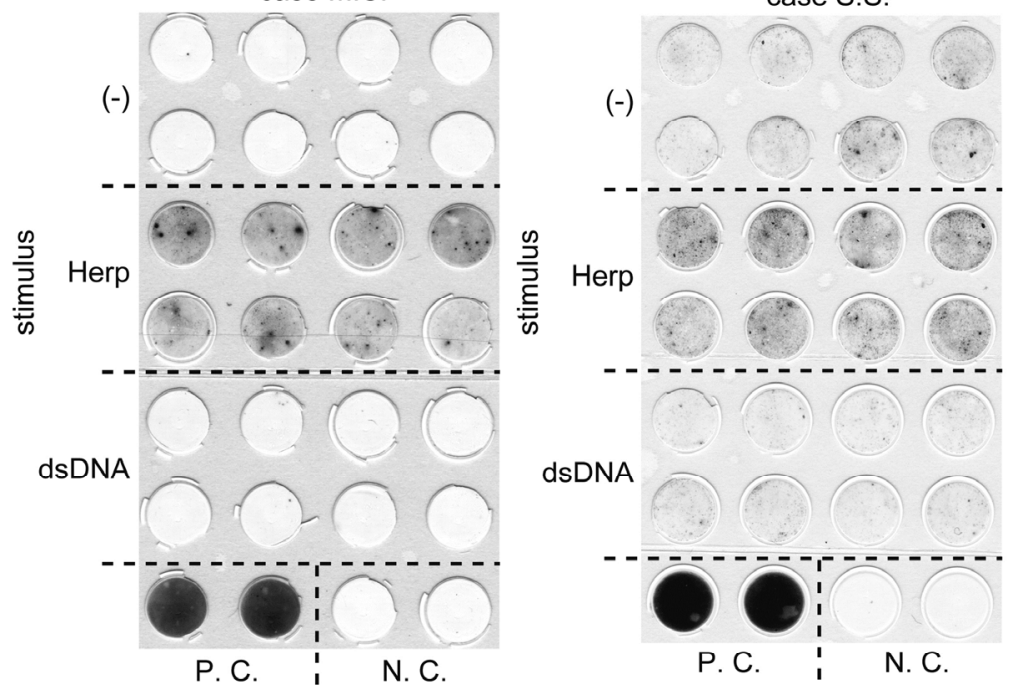

C case R.S.

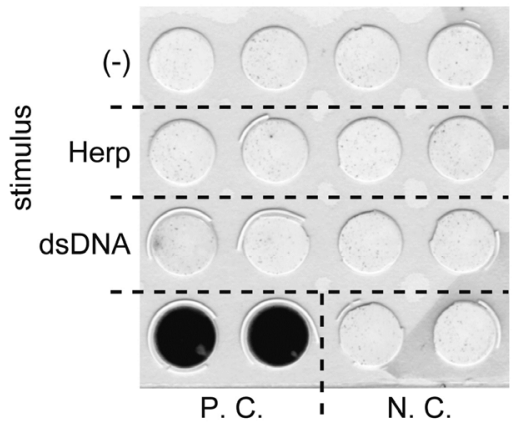

Figure 3. Herp can stimulate anti-dsDNA Ab-producing B cells in untreated patients with active SLE. The PBMCs were stimulated with Herp or dsDNA. Anti-dsDNA Ab-producing PBMCs were detected with ELISPOT. Three representative cases (A, Case M. S.; B, Case S. S.; C, Case R. S.) are shown. The lowest row is the positive control (P. C.: human serum with anti-dsDNA Abs, diluted 1:200) and negative control (N. C.; second antibody only).

Immunization with Herp elicits production of not only anti-dsDNA antibodies but also antissDNA antibodies in BALB/c mice. Among several anti-Herp mAbs established in our laboratory, the HT4 anti-Herp mAb cross-reacts specifically with ssDNA [77]. The epitope of the HT4 mAb on Herp, EPAGSNR, was identified by screening a synthetic peptide library. The binding of HT4 mAb to the peptide was competitively inhibited by ssDNA. Immunization of the epitope peptide elicited anti-ssDNA Abs in BALB/c mice. Treatment with chlorpromazine, procainamide, and hydralazine induced Herp expression and apoptosis in HeLa cells. These findings suggest that (i) ER stress and apoptosis by drugs and 
(ii) molecular mimicry between Herp and ssDNA are involved in anti-ssDNA antibody production in drug-induced lupus.

\section{Postulated mechanism of anti-DNA Ab generation}

Autoimmunity is associated with both genetic predisposition and environmental factors [78]. The monozygotic disease concordance rate ranges from $24 \%$ to $57 \%$ (and not $100 \%$ ) for SLE [79]. Most patients with SLE are non-familial sporadic cases. That is, environmental etiologies of SLE may be common. It is well known that environmental factors such as viral infection, UV exposure, chemicals, etc., can trigger clinical onset or flare of SLE [80,81]. However, little is known regarding how those factors elicit anti-DNA antibody production in vivo. These factors, i.e., cell stressors, affect the expression patterns of cellular proteins, resulting in ER stress in some cases.

What is a practical model of this hypothesis? Natural infection with viruses can cause ER stress on a large scale in vivo [80]. ER stress has been shown to increase when viral proteins are produced at high levels, e.g., in virion formation during the active lytic cycle of infection. Epstein-Barr virus (EBV) infection has been suggested to have a causative role in SLE $[82,83]$. The titers of anti-EBV Abs in SLE patients are higher than those of healthy controls [84]. Kang et al. reported that: (i) patients with SLE had an approximately 40-fold increase in EBV viral load compared with controls; (ii) the frequency of EBV-specific CD69+ CD8+ T cells producing IFN- $\gamma$ was higher in patients with SLE than in controls, but the frequency of EBV-specific CD69+ CD4+ T cells producing IFN- $\gamma$ was lower in patients with SLE than in controls; and (iii) the EBV viral loads were positively correlated with the frequency of EBVspecific CD69+ CD8+ T cells but inversely correlated with the frequency of EBV-specific CD69+ CD4+ T cells [85]. Larsen et al. reported that EBV-specific CD8+ T cell responses in patients with SLE are functionally impaired [86]. The defective control of latent EBV infection in patients with SLE may result in recurrent reactivation of EBV. In fact, aberrant expression of BZLF1, which is a hallmark of EBV lytic infection, has been detected in the PBMCs of SLE patients [87]. In primary EBV infection, EBV infects tonsillar B cells in which lytic replication occurs, and differentiation of latently EBV-infected B cells to plasma cells in lymphoid tissues is associated with induction of the EBV lytic cycle [88]. Herp is expressed in BZLF1-positive EBV-infected B cells (Figure 4).

[Methods] EBV-transformed B cells were fixed in 50\% acetone $/ 50 \%$ methanol for $20 \mathrm{~min}$ at $20^{\circ} \mathrm{C}$ and blocked with 5\% normal goat serum and 3\% BSA in PBS overnight at $4{ }^{\circ} \mathrm{C}$. The cells were stained with DAPI. The cells were then co-stained with HT4 mouse IgG2a antihuman Herp mAb and mouse IgG1 anti-BZLF1 mAb (Dako, Glostrup, Denmark) for $1 \mathrm{~h}$ at room temperature followed by co-staining with rhodamine-conjugated goat anti-mouse IgG2a Ab (Santa Cruz Biotechnology, Santa Cruz, CA) and FITC-conjugated goat antimouse IgG1 Ab (Santa Cruz Biotechnology) for $1 \mathrm{~h}$ at room temperature.

ER stress, which is induced by the production of viral proteins, causes EBV lytic replication, resulting in the release of virions and intracellular molecules [89]. The Herp produced in cells entering the lytic phase of EBV infection can be recognized by the immune system in 
bright field

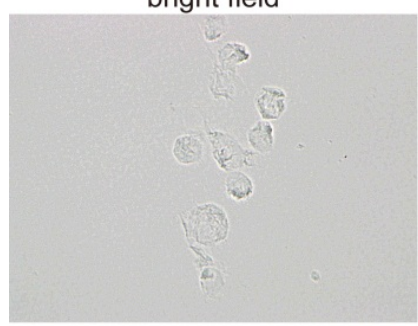

anti-Herp

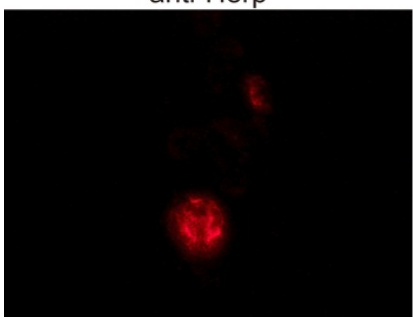

DAPI

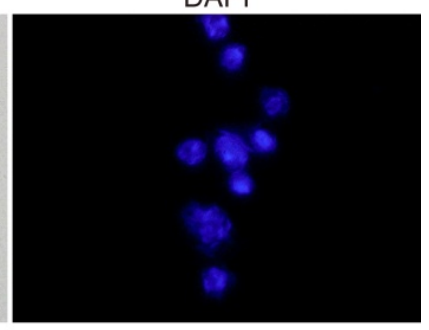

anti-BZLF1

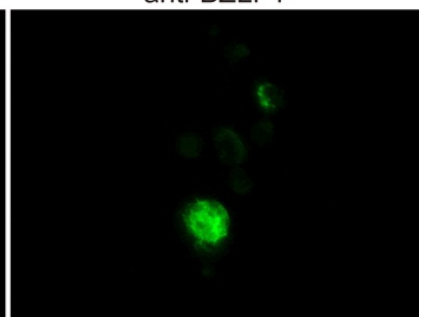

Figure 4. Herp protein is expressed in BZLF1 positive EBV infected B cells.

lymphoid tissues. In addition, EBV-encoded latent membrane protein 2A (LMP2A) induces hypersensitivity to TLR stimulation, leading to activation of autoreactive $B$ cells through the BCR/TLR pathway [90]. Immunization with the membrane fraction of EBV-transformed B cells elicited anti-dsDNA Abs as well as anti-Herp Abs and causes glomerular IgG deposition in BALB/c mice [62]. These observations support the hypothesis that EBV infection may be a trigger of SLE.

This process can repeat during daily life.

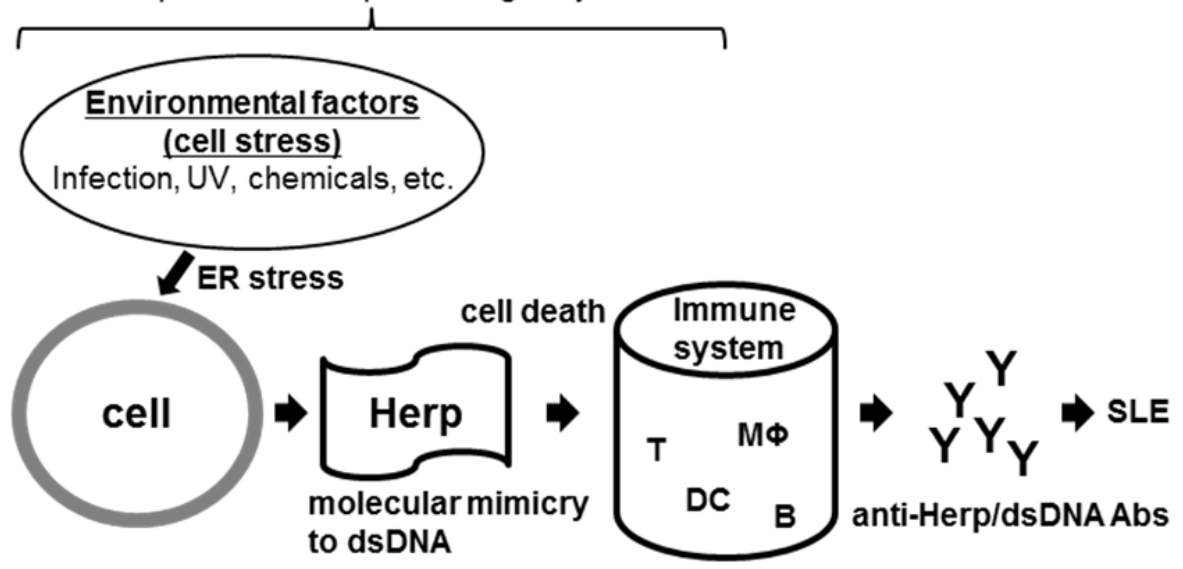

Internal factors: genetic background, epigenetics, nutriture, etc.

Figure 5. Hypothetical mechanism of anti-dsDNA Ab induction. 
The results of the present study led to the following hypothesis in which cell stress triggers an anti-DNA response via Herp in normal individuals: ER stress by environmental factors $\rightarrow$ Herp expression $\rightarrow$ recognition by the immune system of minor epitope(s) mimicking ssDNA I or dsDNA $\rightarrow$ anti-Herp/ssDNA or dsDNA cross-reactive Abs (initial anti-ssDNA or anti-dsDNA Abs) $\rightarrow$ anti-DNA Ab - DNA complex, anti-DNA Ab - nucleosome complex $\rightarrow$ $? \rightarrow$ tissue injury (Figure 5). After the initial production of anti-Herp/DNA Abs, the production of the Abs is stimulated whenever ER stress-induced apoptosis occurs, and the cause of ER stress is not restricted. Repeated cell stress during daily life may strengthen this pathway. Herp is a good candidate as a link between common environmental factors and the etiology of SLE.

\section{Conclusions}

As dead cells are not only a source of intracellular antigens but also a source of proinflammatory molecules, it is likely that they play an important role in the generation of nephritogenic anti-dsDNA Abs. Herp was identified as a molecule directly involved in cell stress/death as the cause of anti-dsDNA Ab production. Further investigations are therefore needed to clarify the relationship between cell stress/death and the etiology of SLE.

\section{Author details}

Yasuhiko Hirabayashi

Department of Rheumatology, Hikarigaoka Spellman Hospital, Japan

Department of Hematology $\mathcal{E}$ Rheumatology, Tohoku University Hospital, Japan

\section{References}

[1] Caricchio R, McPhie L, Cohen PL (2003) Ultraviolet B radiation-induced cell death: critical role of ultraviolet dose in inflammation and lupus autoantigen redistribution. J. Immunol. 171: 5778-5786.

[2] Casciola-Rosen LA, Anhalt G, Rosen A (1994) Autoantigens targeted in systemic lupus erythematosus are clustered in two populations of surface structures on apoptotic keratinocytes. J. Exp. Med. 179: 1317-1330.

[3] Utz PJ, Gensler TJ, Anderson P (2000) Death, autoantigen modifications, and tolerance. Arthritis Res. 2: 101-114.

[4] Darrah E, Rosen A (2010) Granzyme B cleavage of autoantigens in autoimmunity. Cell Death Differ. 17: 624-632.

[5] Brooks WH, Le Dantec C, Pers JO, Youinou P, Renaudineau Y (2010) Epigenetics and autoimmunity. J. Autoimmun. 34: J207-J219.

[6] Poon IK, Hulett MD, Parish CR (2010) Molecular mechanisms of late apoptotic/necrotic cell clearance. Cell Death Differ. 17: 381-397.

[7] Chen GY, Nuñez G (2010) Sterile inflammation: sensing and reacting to damage. Nat. Rev. Immunol. 10: 826-837. 
[8] Pisetsky D (2011) Cell death in the pathogenesis of immune-mediated diseases: the role of HMGB1 and DAMP-PAMP complexes. Swiss Med. Wkly. 141: w13256.

[9] Harris HE, Andersson U, Pisetsky DS (2012) HMGB1: A multifunctional alarmin driving autoimmune and inflammatory disease. Nat Rev Rheumatol 8: 195-202.

[10] Huggins ML, Todd I, Cavers MA, Pavuluri SR, Tighe PJ, Powell RJ (1999) Antibodies from systemic lupus erythematosus (SLE) sera define differential release of autoantigens from cell lines undergoing apoptosis. Clin. Exp. Immunol. 118: 322-328.

[11] Perniok A, Wedekind F, Herrmann M, Specker C, Schneider M (1998) High levels of circulating early apoptic peripheral blood mononuclear cells in systemic lupus erythematosus. Lupus 7: 113-118.

[12] Gröndal G, Traustadottir KH, Kristjansdottir H, Lundberg I, Klareskog L, Erlendsson K, Steinsson K (2002) Increased T-lymphocyte apoptosis/necrosis and IL-10 producing cells in patients and their spouses in Icelandic systemic lupus erythematosus multicase families. Lupus 11: 435-442.

[13] Ren Y, Tang J, Mok MY, Chan AW, Wu A, Lau CS (2003) Increased apoptotic neutrophils and macrophages and impaired macrophage phagocytic clearance of apoptotic neutrophils in systemic lupus erythematosus. Arthritis Rheum. 48: 2888-2897.

[14] Kaplan MJ, Lewis EE, Shelden EA, Somers E, Pavlic R, McCune WJ, Richardson BC (2002) The apoptotic ligands TRAIL, TWEAK, and Fas ligand mediate monocyte death induced by autologous lupus T cells. J. Immunol. 169: 6020-6029.

[15] Courtney PA, Crockard AD, Williamson K, Irvine AE, Kennedy RJ, Bell AL (1999) Increased apoptotic peripheral blood neutrophils in systemic lupus erythematosus: relations with disease activity, antibodies to double stranded DNA, and neutropenia. Ann. Rheum. Dis. 58: 309-314.

[16] Kaplan MJ (2004) Apoptosis in systemic lupus erythematosus. Clin. Immunol. 112: 210218.

[17] Muñoz LE, Janko C, Grossmayer GE, Frey B, Voll RE, Kern P, Kalden JR, Schett G, Fietkau R, Herrmann M and Gaipl US, (2009) Remnants of secondarily necrotic cells fuel inflammation in systemic lupus erythematosus. Arthritis Rheum. 60: 1733-1742.

[18] Muñoz LE, Lauber K, Schiller M, Manfredi AA, Herrmann M (2010) The role of defective clearance of apoptotic cells in systemic autoimmunity. Nat Rev Rheumatol 6: 280-289.

[19] Muñoz LE, Janko C, Schulze C, Schorn C, Sarter K, Schett G, Herrmann M (2010) Autoimmunity and chronic inflammation - two clearance-related steps in the etiopathogenesis of SLE. Autoimmun. Rev. 10: 38-42.

[20] Wiegand UK, Corbach S, Prescott AR, Savill J, Spruce BA (2001) The trigger to cell death determines the efficiency with which dying cells are cleared by neighbours. Cell Death Differ. 8: 734-746. 
[21] Chen XW, Shen Y, Sun CY, Wu FX, Chen Y, Yang CD (2011) Anti-class a scavenger receptor autoantibodies from systemic lupus erythematosus patients impair phagocytic clearance of apoptotic cells by macrophages in vitro. Arthritis Res. Ther. 13: R9.

[22] Voll RE, Herrmann M, Roth EA, Stach C, Kalden JR, Girkontaite I (1997) Immunosuppressive effects of apoptotic cells. Nature 390: 350-351.

[23] Sule S, Rosen A, Petri M, Akhter E, Andrade F (2011) Abnormal production of pro- and anti-inflammatory cytokines by lupus monocytes in response to apoptotic cells. PLoS One 6: e17495.

[24] Kaplan MJ, (2011) Neutrophils in the pathogenesis and manifestations of SLE. Nat Rev Rheumatol 7: 691-699.

[25] Amulic B, Cazalet C, Hayes GL, Metzler KD, Zychlinsky A (2012) Neutrophil function: from mechanisms to disease. Annu. Rev. Immunol. 30: 459-489.

[26] Liu CL, Tangsombatvisit S, Rosenberg JM, Mandelbaum G, Gillespie EC, Gozani OP, Alizadeh AA, Utz PJ (2012) Specific post-translational histone modifications of neutrophil extracellular traps as immunogens and potential targets of lupus autoantibodies. Arthritis Res. Ther. 14: R25.

[27] Denny MF, Yalavarthi S, Zhao W, Thacker SG, Anderson M, Sandy AR, McCune WJ, Kaplan MJ (2010) A distinct subset of proinflammatory neutrophils isolated from patients with systemic lupus erythematosus induces vascular damage and synthesizes type I IFNs. J. Immunol. 184: 3284-3297.

[28] Villanueva E, Yalavarthi S, Berthier CC, Hodgin JB, Khandpur R, Lin AM, Rubin CJ, Zhao W, Olsen SH, Klinker M, Shealy D, Denny MF, Plumas J, Chaperot L, Kretzler M, Bruce AT, Kaplan MJ (2011) Netting neutrophils induce endothelial damage, infiltrate tissues, and expose immunostimulatory molecules in systemic lupus erythematosus. J. Immunol. 187: 538-552.

[29] Hakkim A, Fürnrohr BG, Amann K, Laube B, Abed UA, Brinkmann V, Herrmann M, Voll RE, Zychlinsky A, (2010) Impairment of neutrophil extracellular trap degradation is associated with lupus nephritis. Proc. Natl. Acad. Sci. U. S. A. 107: 9813-9818.

[30] Leffler J, Martin M, Gullstrand B, Tydén H, Lood C, Truedsson L, Bengtsson AA, Blom AM (2012) Neutrophil extracellular traps that are not degraded in systemic lupus erythematosus activate complement exacerbating the disease. J. Immunol. 188: 35223531.

[31] Beyer C, Pisetsky DS (2010) The role of microparticles in the pathogenesis of rheumatic diseases. Nat Rev Rheumatol 6: 21-29.

[32] Pisetsky DS, Gauley J, Ullal AJ (2011) Microparticles as a source of extracellular DNA. Immunol. Res. 49: 227-234.

[33] Ullal AJ, Reich CF, Clowse M, Criscione-Schreiber LG, Tochacek M, Monestier M, Pisetsky DS (2011) Microparticles as antigenic targets of antibodies to DNA and nucleosomes in systemic lupus erythematosus. J. Autoimmun. 36: 173-180. 
[34] Pisetsky DS (2012) Microparticles as autoantigens: making immune complexes big. Arthritis Rheum. 64: 958-961.

[35] Hughes GR, Cohen SA, Christian CL (1971) Anti-DNA activity in systemic lupus erythematosus. A diagnostic and therapeutic guide. Ann. Rheum. Dis. 30: 259-264.

[36] Winfield JB, Faiferman I, Koffler D (1977) Avidity of anti-DNA antibodies in serum and IgG glomerular eluates from patients with systemic lupus erythematosus. Association of high avidity antinative DNA antibody with glomerulonephritis. J. Clin. Invest. 59: 9096.

[37] Madaio MP, Hodder S, Schwartz RS, Stollar BD (1984) Responsiveness of autoimmune and normal mice to nucleic acid antigens. J. Immunol. 132: 872-876.

[38] Desai DD, Krishnan MR, Swindle JT, Marion TN (1993) Antigen-specific induction of antibodies against native mammalian DNA in nonautoimmune mice. J. Immunol. 151: 1614-1626.

[39] Rekvig OP, Moens U, Fredriksen K, Traavik T (1997) Human polyomavirus BK and immunogenicity of mammalian DNA: a conceptual framework. Methods 11: 44-54.

[40] Marchini B, Puccetti A, Dolcher MP, Madaio MP, Migliorini P (1995) Induction of antiDNA antibodies in non autoimmune mice by immunization with a DNA-DNAase I complex. Clin. Exp. Rheumatol. 13: 7-10.

[41] Voynova EN, Tchorbanov AI, Todorov TA, Vassilev TL (2005) Breaking of tolerance to native DNA in nonautoimmune mice by immunization with natural protein/DNA complexes. Lupus 14: 543-550.

[42] Decker P (2006) Nucleosome autoantibodies. Clin. Chim. Acta. 366: 48-60.

[43] Mohan C, Adams S, Stanik V, Datta SK (1993) Nucleosome: a major immunogen for pathogenic autoantibody-inducing T cells of lupus. J. Exp. Med. 177: 1367-1381.

[44] Urbonaviciute V, Fürnrohr BG, Meister S, Munoz L, Heyder P, De Marchis F, Bianchi ME, Kirschning C, Wagner H, Manfredi AA, Kalden JR, Schett G, Rovere-Querini P, Herrmann M, Voll RE (2008) Induction of inflammatory and immune responses by HMGB1-nucleosome complexes: implications for the pathogenesis of SLE. J. Exp. Med. 205: 3007-3018.

[45] Zack DJ, Yamamoto K, Wong AL, Stempniak M, French C, Weisbart RH (1995) DNA mimics a self-protein that may be a target for some anti-DNA antibodies in systemic lupus erythematosus. J. Immunol. 154: 1987-1994.

[46] Sun KH, Tang SJ, Wang YS, Lin WJ, You RI (2003) Autoantibodies to dsDNA cross-react with the arginine-glycine-rich domain of heterogeneous nuclear ribonucleoprotein A2 (hnRNP A2) and promote methylation of hnRNP A2. Rheumatology (Oxford) 42: 154161.

[47] DeGiorgio LA, Konstantinov KN, Lee SC, Hardin JA, Volpe BT, Diamond B (2001) A subset of lupus anti-DNA antibodies cross-reacts with the NR2 glutamate receptor in systemic lupus erythematosus. Nat. Med. 7: 1189-1193. 
[48] Mostoslavsky G, Fischel R, Yachimovich N, Yarkoni Y, Rosenmann E, Monestier M, Baniyash M, Eilat D (2001) Lupus anti-DNA autoantibodies cross-react with a glomerular structural protein: a case for tissue injury by molecular mimicry. Eur. J. Immunol. 31: 1221-1227.

[49] Deocharan B, Qing X, Lichauco J, Putterman C (2002) Alpha-actinin is a cross-reactive renal target for pathogenic anti-DNA antibodies. J. Immunol. 168: 3072-3078.

[50] Tsuzaka K, Leu AK, Frank MB, Movafagh BF, Koscec M, Winkler TH, Kalden JR, Reichlin M (1996) Lupus autoantibodies to double-stranded DNA cross-react with ribosomal protein S1. J. Immunol. 156: 1668-1675.

[51] Lafer EM, Rauch J, Andrzejewski C, Mudd D, Furie B, Furie B, Schwartz RS, Stollar BD (1981) Polyspecific monoclonal lupus autoantibodies reactive with both polynucleotides and phospholipids. J. Exp. Med. 153: 897-909.

[52] Gaynor B, Putterman C, Valadon P, Spatz L, Scharff MD, Diamond B (1997) Peptide inhibition of glomerular deposition of an anti-DNA antibody. Proc. Natl. Acad. Sci. U. S. A. 94: 1955-1960.

[53] Putterman C, Diamond B (1998) Immunization with a peptide surrogate for doublestranded DNA (dsDNA) induces autoantibody production and renal immunoglobulin deposition. J. Exp. Med. 188: 29-38.

[54] Yadav P, Tran H, Ebegbe R, Gottlieb P, Wei H, Lewis RH, Mumbey-Wafula A, Kaplan A, Kholdarova E, Spatz L (2011) Antibodies elicited in response to EBNA-1 may crossreact with dsDNA. PLoS One 6: e14488.

[55] Tamate E, Sasaki T, Muryoi T, Takai O, Otani K, Tada K, Yoshinaga K (1986) Expression of idiotype on the surface of human B cells producing anti-DNA antibody. J. Immunol. 136: 1241-1246.

[56] Sasaki T, Hatakeyama A, Shibata S, Osaki H, Suzuki M, Horie K, Kitagawa Y, Yoshinaga K (1991) Heterogeneity of immune complex-derived anti-DNA antibodies associated with lupus nephritis. Kidney Int. 39: 746-753.

[57] Suzuki M, Hatakeyama A, Kameoka J, Tamate E, Yusa A, Kurosawa K, Saito T, Sasaki T, Yoshinaga K (1991) Anti-DNA idiotypes deposited in renal glomeruli of patients with lupus nephritis. Am. J. Kidney Dis. 18: 232-239.

[58] Shibata S, Sasaki T, Hatakeyama A, Munakata Y, Hirabayashi Y, Yoshinaga K (1992) Clonal frequency analysis of $\mathrm{B}$ cells producing pathogenic anti-DNA antibodyassociated idiotypes in systemic lupus erythematosus. Clin. Immunol. Immunopathol. 63: 252-258.

[59] Suzuki Y, Funato T, Munakata Y, Sato K, Hirabayashi Y, Ishii T, Takasawa N, Ootaka T, Saito T, Sasaki T (2000) Chemically modified ribozyme to V gene inhibits anti-DNA production and the formation of immune deposits caused by lupus lymphocytes. J. Immunol. 165: 5900-5905. 
[60] Hirabayashi Y, Munakata Y, Sasaki T, Sano H (1992) Variable regions of a human antiDNA antibody O-81 possessing lupus nephritis-associated idiotype. Nucleic Acids Res. 20: 2601.

[61] Munakata Y, Saito S, Hoshino A, Muryoi T, Hirabayashi Y, Shibata S, Miura T, Ishii T, Funato T, Sasaki T (1998) Somatic mutation in autoantibody-associated VH genes of circulating IgM+IgD+ B cells. Eur. J. Immunol. 28: 1435-1444.

[62] Hirabayashi Y, Oka Y, Ikeda T, Fujii H, Ishii T, Sasaki T, Harigae H (2010) The endoplasmic reticulum stress-inducible protein, Herp, is a potential triggering antigen for anti-DNA response. Journal of Immunology 184: 3276-3283.

[63] Oka Y, Hirabayashi Y, Ishii T, Takahashi R, Sasaki T (2007) A monoclonal antibody against human homocysteine-induced endoplasmic reticulum protein (Herp): a useful tool for evaluating endoplasmic reticulum stress. Tohoku J. Exp. Med. 212: 431-437.

[64] Puthalakath H, O'Reilly LA, Gunn P, Lee L, Kelly PN, Huntington ND, Hughes PD, Michalak EM, McKimm-Breschkin J, Motoyama N, Gotoh T, Akira S, Bouillet P, Strasser A (2007) ER stress triggers apoptosis by activating BH3-only protein Bim. Cell 129: 1337-1349.

[65] Shore GC, Papa FR, Oakes SA (2011) Signaling cell death from the endoplasmic reticulum stress response. Curr. Opin. Cell Biol. 23: 143-149.

[66] Bruns A, Bläss S, Hausdorf G, Burmester GR, Hiepe F (2000) Nucleosomes are major T and B cell autoantigens in systemic lupus erythematosus. Arthritis Rheum. 43: 23072315.

[67] Radic M, Marion T, Monestier M (2004) Nucleosomes are exposed at the cell surface in apoptosis. J. Immunol. 172: 6692-6700.

[68] Gómez-Puerta JA, Burlingame RW, Cervera R (2008) Anti-chromatin (anti-nucleosome) antibodies: diagnostic and clinical value. Autoimmun. Rev. 7: 606-611.

[69] van Bruggen MC, Kramers C, Walgreen B, Elema JD, Kallenberg CG, van den Born J, Smeenk RJ, Assmann KJ, Muller S, Monestier M, Berden JH (1997) Nucleosomes and histones are present in glomerular deposits in human lupus nephritis. Nephrol. Dial. Transplant 12: 57-66.

[70] O'Flynn J, Flierman R, van der Pol P, Rops A, Satchell SC, Mathieson PW, van Kooten C, van der Vlag J, Berden JH, Daha MR (2011) Nucleosomes and C1q bound to glomerular endothelial cells serve as targets for autoantibodies and determine complement activation. Mol. Immunol. 49: 75-83.

[71] Muller S, Dieker J, Tincani A, Meroni PL (2008) Pathogenic anti-nucleosome antibodies. Lupus 17: 431-436.

[72] Rubin RL (2005) Drug-induced lupus. Toxicology 209: 135-147.

[73] Marzano AV, Vezzoli P, Crosti C (2009) Drug-induced lupus: an update on its dermatologic aspects. Lupus 18: 935-940.

[74] Lee BH, Yegnasubramanian S, Lin X, Nelson WG (2005) Procainamide is a specific inhibitor of DNA methyltransferase 1. J. Biol. Chem. 280: 40749-40756. 
[75] Deng C, Lu Q, Zhang Z, Rao T, Attwood J, Yung R, Richardson B (2003) Hydralazine may induce autoimmunity by inhibiting extracellular signal-regulated kinase pathway signaling. Arthritis Rheum. 48: 746-756.

[76] Strickland FM, Richardson BC (2008) Epigenetics in human autoimmunity. Epigenetics in autoimmunity - DNA methylation in systemic lupus erythematosus and beyond. Autoimmunity 41: 278-286.

[77] Oka Y, Hirabayashi Y, Ikeda T, Fujii H, Ishii T, Harigae H (2011) A single-stranded DNA-cross-reactive immunogenic epitope of human homocysteine-inducible endoplasmic reticulum protein. Scand. J. Immunol. 74: 296-303.

[78] Christen U, von Herrath MG (2004) Initiation of autoimmunity. Curr. Opin. Immunol. 16: 759-767.

[79] Wandstrat A, Wakeland E (2001) The genetics of complex autoimmune diseases: nonMHC susceptibility genes. Nat. Immunol. 2: 802-809.

[80] He B (2006) Viruses, endoplasmic reticulum stress, and interferon responses. Cell Death Differ. 13: 393-403.

[81] Komori R, Taniguchi M, Ichikawa Y, Uemura A, Oku M, Wakabayashi S, Higuchi K, Yoshida H (2012) Ultraviolet a induces endoplasmic reticulum stress response in human dermal fibroblasts. Cell Struct. Funct. 37: 49-53.

[82] James JA, Kaufman KM, Farris AD, Taylor-Albert E, Lehman TJ, Harley JB (1997) An increased prevalence of Epstein-Barr virus infection in young patients suggests a possible etiology for systemic lupus erythematosus. J. Clin. Invest. 100: 3019-3026.

[83] Niller HH, Wolf H, Minarovits J (2008) Regulation and dysregulation of Epstein-Barr virus latency: implications for the development of autoimmune diseases. Autoimmunity 41: 298-328.

[84] Fattal I, Shental N, Mevorach D, Anaya JM, Livneh A, Langevitz P, Zandman-Goddard G, Pauzner R, Lerner M, Blank M, Hincapie ME, Gafter U, Naparstek Y, Shoenfeld Y, Domany E, Cohen IR (2010) An antibody profile of systemic lupus erythematosus detected by antigen microarray. Immunology 130: 337-343.

[85] Kang I, Quan T, Nolasco H, Park SH, Hong MS, Crouch J, Pamer EG, Howe JG, Craft J (2004) Defective control of latent Epstein-Barr virus infection in systemic lupus erythematosus. J. Immunol. 172: 1287-1294.

[86] Larsen M, Sauce D, Deback C, Arnaud L, Mathian A, Miyara M, Boutolleau D, Parizot C, Dorgham K, Papagno L, Appay V, Amoura Z, Gorochov G (2011) Exhausted cytotoxic control of Epstein-Barr virus in human lupus. PLoS Pathog 7: e1002328.

[87] Gross AJ, Hochberg D, Rand WM, Thorley-Lawson DA (2005) EBV and systemic lupus erythematosus: a new perspective. J. Immunol. 174: 6599-6607.

[88] Laichalk LL, Thorley-Lawson DA (2005) Terminal differentiation into plasma cells initiates the replicative cycle of Epstein-Barr virus in vivo. J. Virol. 79: 1296-1307.

[89] Taylor GM, Raghuwanshi SK, Rowe DT, Wadowsky RM, Rosendorff A (2011) Endoplasmic reticulum stress causes EBV lytic replication. Blood 118: 5528-5539. 
[90] Wang H, Nicholas MW, Conway KL, Sen P, Diz R, Tisch RM, Clarke SH (2006) EBV latent membrane protein $2 \mathrm{~A}$ induces autoreactive $\mathrm{B}$ cell activation and TLR hypersensitivity. J. Immunol. 177: 2793-2802. 